\title{
Article \\ Trichoderma Biomass as an Alternative for Removal of Congo Red and Malachite Green Industrial Dyes
}

\author{
Rosalba Argumedo-Delira ${ }^{1,2, * \mathbb{C}}$, Mario J. Gómez-Martínez ${ }^{3}\left(\mathbb{D}\right.$ and Ramiro Uribe-Kaffure ${ }^{4}$ (D) \\ 1 Instituto de Química Aplicada (IQA), Universidad Veracruzana, Luis Castelazo Ayala s/n, \\ Col. Industrial Animas, Xalapa, Veracruz 91190, Mexico \\ 2 Posgrado en Ciencias Agropecuarias, Facultad de Ciencias Agrícolas, Universidad Veracruzana, \\ Circuito Gonzalo Aguirre Beltrán s/n, Xalapa, Veracruz 91000, Mexico \\ 3 Departamento de Producción y Sanidad Vegetal, Facultad de Ingeniería Agronómica, Universidad del Tolima, \\ Barrio Santa Helena, Ibagué, Tolima 730006299, Colombia; migomez@ut.edu.co \\ 4 Departamento de Física, Facultad de Ciencias, Universidad del Tolima, Barrio Santa Helena, Ibagué, \\ Tolima 730006299, Colombia; rauribe@ut.edu.co \\ * Correspondence: rargumedo@uv.mx; Tel.: +52-011-5222-8842-1700 (ext. 13917)
}

Citation: Argumedo-Delira, R.;

Gómez-Martínez, M.J.; Uribe-Kaffure, R.

Trichoderma Biomass as an Alternative for Removal of Congo Red and Malachite Green Industrial Dyes. Appl. Sci. 2021, 11, 448. https://doi.org/10.3390/ app11010448

Received: 3 November 2020 Accepted: 31 December 2020 Published: 5 January 2021

Publisher's Note: MDPI stays neutral with regard to jurisdictional clai$\mathrm{ms}$ in published maps and institutional affiliations.

Copyright: () 2021 by the authors. Licensee MDPI, Basel, Switzerland. This article is an open access article distributed under the terms and conditions of the Creative Commons Attribution (CC BY) license (https:// creativecommons.org/licenses/by/ $4.0 /)$.

\begin{abstract}
The present study evaluated the removal efficiency of two dyes, Congo red (CR) and malachite green (MG), using either fresh or dry fungal biomass of two species of Trichoderma (T. virens and T. viride) and activated carbon. After $24 \mathrm{~h}$, the CR removal efficiency obtained with fresh biomass was higher than that obtained with activated carbon. For the MG dye, the average removal with activated carbon (99\%) was higher than those obtained with dry and fresh biomass of T. viride and T. virens. Experimental results for fresh and dry fungal biomass showed a good correlation with Langmuir isotherms. The adsorption rates of CR and MG by of T. virens and T. viride can be more appropriately described using the pseudo-second-order rate. We found an adsorption capacity of $81.82 \mathrm{mg} \mathrm{g}^{-1}$ for $T$. virens with MG dye. Results show that fresh or dry biomass of T. virens can represent a simple and cost-effective alternative for removing industrial dyes such as CR and MG.
\end{abstract}

Keywords: industrial dyes; T. virens; T. viride; fresh fungal biomass; dry fungal biomass

\section{Introduction}

Synthetic dyes released from textile, cosmetic, paper, and food industries have potentially adverse environmental and health impacts since they not only affect the quality and aesthetic of water but can also be associated with mutagenic, carcinogenic, and allergenic risk [1-5]. Thus, working on new alternatives to remove materials is relevant.

Dyes are complex organic molecules with several recalcitrant aromatic rings classified as anionic (acid), cationic (basic), and non-ionic [6]. They consist of chromophores, which are responsible for giving color, and the auxochromes charge intensifies the color of dyes. Acidic dyes are water-soluble compounds containing one or more anionic groups (salts of sulfuric, carboxylic, phenolic groups). Basic dyes are cationic molecules that have monoazoic, diazoic, and azine compounds.

Among diverse synthetic dyes, Congo red (CR) and malachite green (MG) are two of the most commons due to their low cost, high availability, and efficacy. CR is the sodium salt of benzidinediazo-bis-1-naphthylamine-4-sulfonic acid $\left(\mathrm{C}_{32} \mathrm{H}_{22} \mathrm{~N}_{6} \mathrm{Na}_{2} \mathrm{O}_{6} \mathrm{~S}_{2} ;\right.$ molecular weight: $696.66 \mathrm{~g} \mathrm{~mol}^{-1}$ ) (Figure 1A). It is an azo acid dye that is very soluble in water, which directly stains cotton in red; it may also turn blue by the presence of mineral acids. $\mathrm{CR}$ is also used for staining some products in the wood pulp and paper industry $[7,8]$. $\mathrm{MG}$, the most common basic dye (N-methylated diaminotriphenylmethane; $\mathrm{C}_{52} \mathrm{H}_{54} \mathrm{~N}_{4} \mathrm{O}_{12}$; molecular weight: $927.00 \mathrm{~g} \mathrm{~mol}^{-1}$ ) (Figure 1B), has been widely used as a bactericide and fungicide in the fish farming industry, in the coloring of silk, and as a food coloring agent and additive $[9,10]$. 


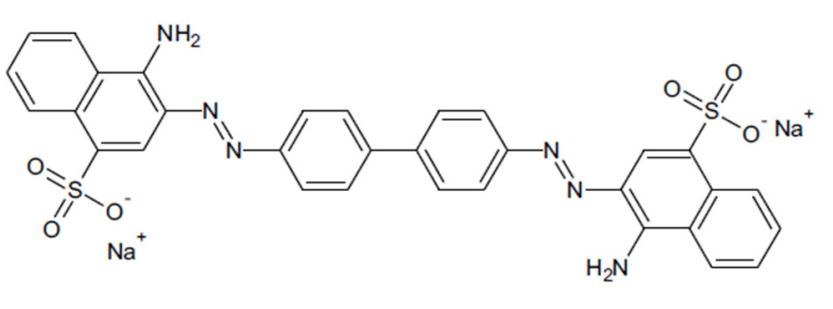

B $\quad \mathrm{Cl}^{-}$

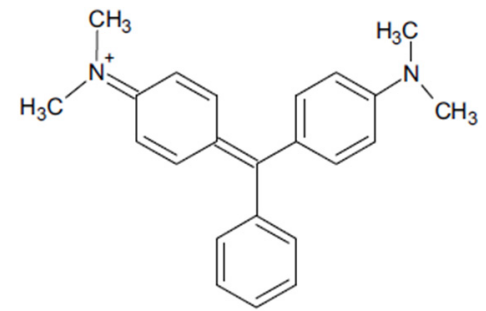

Figure 1. Chemical structure of the Congo red (A) and malachite green (B) dyes.

The importance of studying dyes such as CR and MG lies in the fact that they are resistant to natural degradation processes. The aromatic rings provide the dye molecules with chemical stability, so organisms require more energy to mineralize these substances [11,12]. That is to say, since the dye's mineralization process becomes slow, the greater the number of aromatic rings, the longer their persistence in the environment, which could lead to a negative effect on the aquatic flora and fauna [12,13]. Additionally, they are susceptible to being reduced, which results in the formation of aromatic amines that are highly carcinogenic [10,14-16].

To reduce the pollution caused by these two dyes, either chemical, physical, or biological methods have been used [16-18]. Some chemical dye removal methods are the advanced oxidation process, ozonation, photochemical, electrochemical destruction, and Fenton reaction. Most of these dye removal methods are effective, quick, and do not generate sludge. However, they could produce undesirable by-products, and in general, they are costly compared to biological and physical dye removal methods. Among conventional physical dye removal methods are adsorption by activated carbon, membrane filtration, ion exchange, electrokinetic flocculation, irradiation, reverse osmosis, and ultra-filtration. Physical methods are commonly used due to their efficiency and simplicity; nevertheless, they are effective for a limited number of dyes, and some of them show high sludge production. On the other hand, biological methods such as adsorption by microbial biomass, algae degradation, fungal cultures, adsorption by living/dead microbial biomass, and enzyme degradation, among others, have gained importance used alone or as a combined method, because they are ecofriendly and do not need the consumption of chemicals. However, these methods deal with living organisms, so they are sometimes considered unstable or unpredictable [19-23].

Among biological treatment with microorganisms, it has been found that the use of living or dead microbial biomass (from bacteria, yeasts, fungi or microalgae) can play a key role in decolorizing the wastewater of different industries without producing toxic substances [24-26]. Microbial biomass is a low-cost product obtained as a residue of the fermentation processes in the production of antibiotics, beverages, enzymes, and other metabolites. However, it has been reported that the use of live biomass in the processes of biosorption of dyes presents some disadvantages, such as the need for a continuous supply of nutrients and high sensitivity to the dye toxicity [27]. Therefore, a lot of research has focused on using dead biomass for biosorption processes, since it does not require continuous nutrient supply and is not affected by toxic waste [28]; likewise, its regeneration is simple, can be stored for long periods at room temperature, can be reused for many cycles, and can be easily immobilized on inert supports [26].

The surface properties of bacteria, yeasts, fungi, and algae allow them to interact with different types of contaminants. In particular, in the process of dye biosorption, microbial biomass can use mechanisms such as physical and chemical adsorption, electrostatic interaction, ion exchange, complexation, chelation, and micro-precipitation [29]. Thus, the biosorption process will depend on the dye chemical nature (specie, size, ionic charge), type of biomass, specific surface properties, environmental conditions ( $\mathrm{pH}$, temperature, ionic strength), and presence of organic compounds, salts, and competing ions [26].

Fungal adsorption by living or dead biomass is commonly used as biological treatments for dye removal in aqueous media. Fungal biomass contains a large number of 
functional groups, which gives its cell surface a negative charge that allows the efficient biosorption of dyes [30,31]. However, the process of dye biosorption for fungal biomass can be slow, and the initial $\mathrm{pH}$ of the dye solution strongly influences the biosorption [3,32,33].

Filamentous fungi such as Aspergillus niger, Phanerochaete chrysosporium, Rhizopus arrhizus, Cuninghamella elegans, Ganoderma applanatum, and Pleurotus ostreatus, among others, have been assessed as an alternative strategy for removing and degrading dyes under in vitro conditions [34-41]. Concerning the Trichoderma species, previous works have reported that $T$. harzianum can remove or discolor Rhodamine 6G and Trypan Blue Erioglaucine, and can favor the biosorption of the Orange G dye [42-46]. In addition, researchers have shown the potential of T. viride for the removal of methylene blue [47]. However, more research is needed to determine the true potential of these species for decolorizing polluted waters.

The genus Trichoderma comprises a predominant group of filamentous fungi in terrestrial and aquatic ecosystems widely used in the control of phytopathogenic organisms and industrial processes [48-51]. The advantages of using species of the genus Trichoderma in the biosorption of dyes are its easy availability, low cost, good mechanical properties, and chemical stability under both alkaline and acid conditions [52]. In this regard, the present study evaluated the capability of either fresh or dry biomass of T. virens and T. viride to remove CR and MG under several dye concentrations. These fungi were selected due to their tolerance to high concentrations of polycyclic aromatic hydrocarbons [53]. In addition, to carry out an objective comparison, under the same conditions, additional absorption experiments were carried out with activated carbon as the sorbent.

\section{Materials and Methods}

\subsection{Fresh Biomass of T. virens and T. viride}

The fungi T. virens (CP1) and T. viride (CP4) were previously isolated from rhizosphere soil of mesquite (Prosopis sp.) in the state of Jalisco, Mexico [54]. The two strains of Trichoderma were reactivated in Petri dishes with potato dextrose (PDA, Merck ${ }^{\circledR}$, State of Mexico, Mexico) at $28{ }^{\circ} \mathrm{C}$ for 5 days and then grown in $50 \mathrm{~mL}$ of mineral medium $\left(\mathrm{g} \mathrm{L}^{-1}\right)$ $0.1 \mathrm{CaCl}_{2} ; 0.2 \mathrm{KCl}, 0.5 \mathrm{KH}_{2} \mathrm{PO}_{4} ; 0.5\left(\mathrm{NH}_{4}\right)_{2} \mathrm{SO}_{4} ; 0.2 \mathrm{MgSO}_{4} \cdot 7 \mathrm{H}_{2} \mathrm{O} ; 0.05 \mathrm{CuSO}_{4} ; 0.05 \mathrm{ZnSO}_{4}$; $0.43 \mathrm{MnSO}_{4} ; 0.05\left(\mathrm{NH}_{4}\right)_{6} \mathrm{Mo}_{7} \mathrm{O}_{24} \cdot \mathrm{H}_{2} \mathrm{O}, 6$ glucose, and $\mathrm{pH}$ 4.3. After six days of incubation, the living mycelium (fresh biomass) was vacuum filtered under sterile conditions. Then, half of the mycelium of each fungal isolate was washed with $50 \mathrm{~mL}$ of sterile distilled water and transferred to a $150 \mathrm{~mL}$ flask with $50 \mathrm{~mL}$ of sterile distilled water. The other half of the fresh fungal biomass was exposed to $0.35 \mathrm{~g}$ of $\mathrm{HgCl}_{2}$ for five days to kill the mycelium and avoid the further synthesis of fungal enzymes [55]. This dead mycelium was subsequently filtrated and washed, as previously described, and placed in $50 \mathrm{~mL}$ of sterile distilled water.

Later on, $100 \mathrm{~mL}$ of a stock solution of CR or MG $\left(1000 \mathrm{mg} \mathrm{L}^{-1}\right)$ were added into each respective treatment (living and dead mycelium) to obtain a final concentration of $50 \mathrm{mg} \mathrm{L}^{-1}$ at $\mathrm{pH}$ 6. The treatments were incubated at $28 \pm 2{ }^{\circ} \mathrm{C}$ at $150 \mathrm{rpm}$ for eight days, sampling every $24 \mathrm{~h}$; then, $300 \mu \mathrm{L}$ of each treatment were transferred to a microplate and analyzed in a multi-modal microplate reader (Synergy 2 SL, Biotek ${ }^{\circledR}$, Winooski, VT, USA) to $541 \mathrm{~nm}(\mathrm{CR})$ and $619 \mathrm{~nm}(\mathrm{MG})$, respectively. The amount of dye removal per unit of fungal biomass was calculated using the following equation:

$$
\text { removal efficiency }(\%)=\frac{C_{\mathrm{i}}-C_{\mathrm{f}}}{C_{\mathrm{i}}} \times 100,
$$

where $C_{\mathrm{i}}$ and $C_{\mathrm{f}}$ represent the initial and final (after adsorption) dye concentrations, respectively.

\subsection{Activated Carbon and Dry Biomass of T. virens and T. viride}

First, $500 \mathrm{~mL}$ of the mineral medium previously described were added to $1000 \mathrm{~mL}$ Erlenmeyer flasks and autoclaved for $18 \mathrm{~min}$ at $120^{\circ} \mathrm{C}$. Then, $10 \mathrm{~mL}$ of a spore suspension $\left(10^{6}\right.$ spores $\left.\mathrm{mL}^{-1}\right)$ of each fungus were subsequently added to each culture. Fungal cultures were incubated at room temperature and pump oxygenated for six days. After incubation, 
the fungal mycelium was vacuum filtered, dried at $70 \pm 2{ }^{\circ} \mathrm{C}$ for $96 \mathrm{~h}$, weighed, and powdered in a mortar.

Removal experiments were carried out by stirring $100 \mathrm{mg}$ of the respective adsorbent material [activated carbon Sigma Aldrich ${ }^{\circledR}$ (State of Mexico, Mexico) and fungal dry biomass] with $1 \mathrm{~mL}$ of $\mathrm{CR}$ or MG at the following concentrations: $0,15,30,45,60,75$, and $90 \mathrm{mg} \mathrm{L}^{-1}$ at $\mathrm{pH} 6$, and incubated at $25^{\circ} \mathrm{C}$ and $150 \mathrm{rpm}$ (TS-100, Biosan ${ }^{\circledR}$, Riga, Latvia). The concentration of each dye was spectrophotometrically estimated by taking absorbance readings at $541 \mathrm{~nm}$ for CR and 619 for MG, using 96-well microplates (Synergy $2 \mathrm{SL}$, Biotek $^{\circledR}$, Winooski, VT, USA). Removal capacity was determined using Equation (1).

\subsubsection{Equilibrium Studies}

The equilibrium relationship between the amount of substance adsorbed at constant temperature $\left(q_{\mathrm{e}}\right)$ and its equilibrium solution concentration $\left(C_{\mathrm{e}}\right)$ is known as adsorption isotherm. The equilibrium adsorption data were analyzed using Langmuir and Freundlich models. The linearized forms of the Langmuir and Freundlich isotherms are given by:

$$
\begin{gathered}
\text { Langmuir Model }: \frac{C_{\mathrm{e}}}{q_{\mathrm{e}}}=\frac{1}{K_{\mathrm{L}} q_{\max }}+\frac{C_{\mathrm{e}}}{q_{\max }}, \\
\text { Freundlich Model }: \log q_{\mathrm{e}}=\log K_{\mathrm{F}}+\frac{1}{n} \log C_{\mathrm{e}},
\end{gathered}
$$

where $q_{\max }\left(\mathrm{mg} \mathrm{g}^{-1}\right)$ is the maximum value of $q_{\mathrm{e}}$ that can be reached as $C_{\mathrm{e}}\left(\mathrm{mg} \mathrm{g}^{-1}\right)$ is increased, $K_{\mathrm{L}}$ is the affinity coefficient $\left(\mathrm{L} \mathrm{mg}^{-1}\right)$, and $K_{\mathrm{F}}$ and $n$ represent the Freundlich coefficients $\left(n\right.$, dimensionless; $\left.K_{\mathrm{F}}, \mathrm{mg} \mathrm{g}^{-1}\right)$.

\subsubsection{Kinetic Studies}

The adsorption kinetics was analyzed with models of pseudo-first and pseudo-second order. The pseudo-first-order model, in its linear form is described by Lagergren:

$$
\log \left(q_{\mathrm{e}}-q_{\mathrm{t}}\right)=\log \left(q_{\mathrm{e}}\right)-\frac{k_{1}}{2.303} t,
$$

where $q_{\mathrm{e}}$ is the adsorption capacity at equilibrium $\left(\mathrm{mg} \mathrm{g}^{-1}\right), q_{\mathrm{t}}$ is the amount of the adsorbate adsorbed by time $t\left(\mathrm{mg} \mathrm{g}^{-1}\right)$, and $k_{1}$ is the pseudo-first-order constant $\left(\mathrm{min}^{-1}\right)$.

The linear form of the pseudo-second-order kinetic model is described by Ho:

$$
\frac{t}{q_{\mathrm{t}}}=\frac{1}{k_{2} q_{\mathrm{e}}^{2}}+\frac{1}{q_{\mathrm{e}}} t
$$

where $k_{2}$ is the pseudo-second-order constant $\left(\mathrm{g} \mathrm{mg}^{-1} \mathrm{~min}^{-1}\right)$.

\subsection{Statistic Analysis}

The experiment for the removal of CR and MG by fresh biomass (with or without $\mathrm{HgCl}_{2}$ treatment) of $T$. virens and $T$. viride was set in a completely randomized experimental design, establishing a $2 \times 2 \times 2$ factorial experiment (two strains of Trichoderma, two dyes, and two conditions of biomass), including eight treatments and three replicates each. Analysis of variance and mean comparison test (Tukey, $\alpha=0.05$ ) were performed using the SAS statistical program.

\section{Results and Discussion}

\subsection{Removal of $C R$ and $M G$ by Fresh Biomass of T. virens and T. viride}

The removal of $\mathrm{CR}$ (Figure 2A) showed no significant differences, from $24 \mathrm{~h}$ onwards, for the living mycelium of T. viride (93\%) and dead mycelium of T. viride (95\%) and T. virens ( $94 \%)$. However, the percentage of CR removal by living T. virens showed a constant increase during the experimentation time from $82.4 \%$ to $93 \%$. In that respect, it has been 
reported that some species pre-adapted to azo dyes show better removal properties than untreated culture media [56].
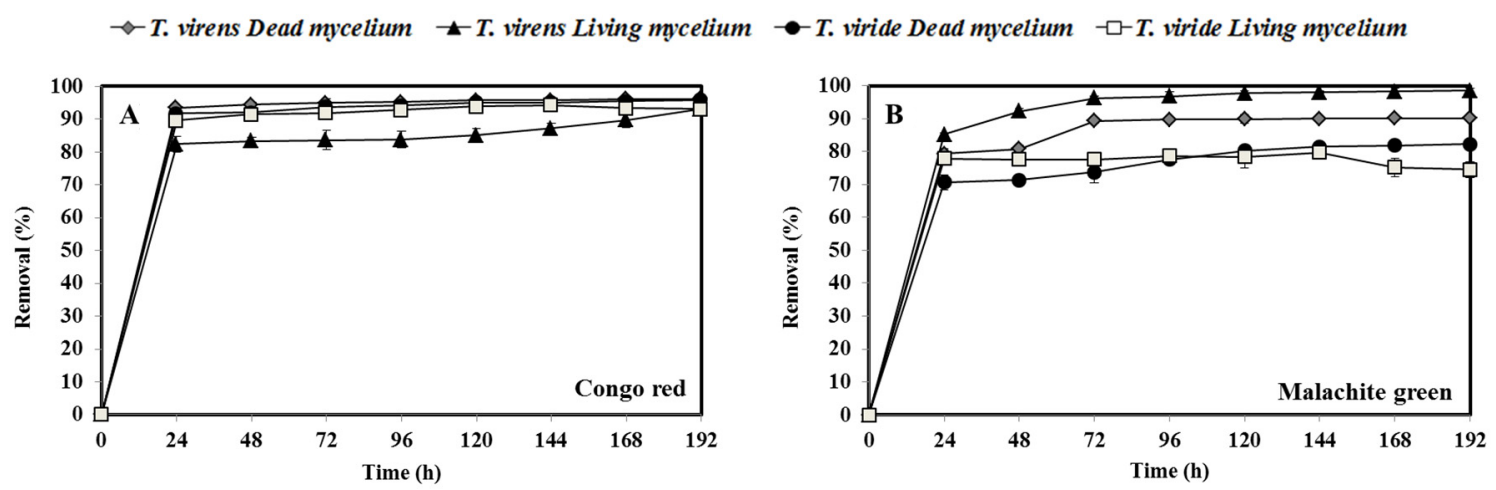

Figure 2. (A) Removal of Congo red $\left(50 \mathrm{mg} \mathrm{L}^{-1}\right)$ and (B) malachite green (50 $\left.\mathrm{mg} \mathrm{L}^{-1}\right)$ by fungal fresh biomass (living or dead), for eight days.

The living mycelium in the two species of Trichoderma had slightly lower removal capability of CR when compared to that described for Trametes versicolor $(100 \%)$ and Thelephora sp. (97\%); however, the concentration of CR used in the present study $\left(50 \mathrm{mg} \mathrm{L}^{-1}\right)$ is higher than those reported for T. versicolor or Thelephora with $31 \mathrm{mg} \mathrm{L}^{-1}$ and $35 \mathrm{mg} \mathrm{L}^{-1}$, respectively [57] (Table 1). In contrast, when the CR concentration was $50 \mathrm{mg} \mathrm{L}^{-1}$, the removal observed for T. versicolor, 82\%, for Aspergillus niger, 9\%, for A. oryzae, 52\%, for Penicillium chrysogenum, $10 \%$, for Cladosporium rubrum, 10\%, and Pleurotus ostreatus, $12 \%$ [58,59], were lower than that obtained in the present study. The removal percentages of CR by the dead mycelium of T. virens ( $94 \%$ ) and T. viride $(95 \%)$ are higher than those described for the mycelium of T. versicolor under three conditions: (a) autoclaved (90\%), (b) acidic (49\%), and (c) alkaline (42\%) [58] (Table 1).

For MG dye (Figure 2B), the living and dead mycelium of T. virens showed the highest removal percentages, $95 \%$ and $87 \%$, respectively. For its part, the dead mycelium $T$. viride showed $82 \%$ of MG removal, whereas the living mycelium showed the lowest removal (75\%). Compared to other fungi, the percentage of MG removal showed by the living mycelium of T. virens $(95 \%)$ and T. viride $(75 \%)$ was higher than that reported for mycelium of the white rot fungus Polyporus elegans (45\%), T. versicolor (43\%), Lenzites betulin (57\%), $P$. simplicissimum (89 and 57\%), P. ochrochloron (93\%), and Mucor (65\%) [60,61] (Table 1).

It has been reported that the biomass of some other filamentous fungi shows a higher capacity for removing CR and MG (Table 1). However, T. viride and T. virens have the advantage of growing rapidly in conventional media and agri-food residues and produce, at low-cost, large quantities of biomass, compared to some strains of Aspergillus niger, Polyporus elegans, T. versicolor, and Pleurotus ostreatus [62-64].

It is worth to note that in this research, $\mathrm{HgCl}_{2}$ was used to kill mycelium and prevent the synthesis of fungal enzymes, according to the methodology of Wunch et al. [55]. However, its use is not recommended because of its environmental implications. Another alternative to kill mycelium in an environmentally friendly way is autoclaving [58]. In addition, autoclaving mycelium has been found to increase the adsorption of fungal biomass [26].

To evaluate the adsorption rate, the data obtained from kinetic experiments were fitted using pseudo-first (Equation (4)) and pseudo-second-order (Equation (5)) reaction rate models. The results indicated that the adsorption rates of CR and MG by T. virens and T. viride could be more appropriately described using the pseudo-second-order rate model (correlation coefficient $R^{2}=0.99$ ). Figure $3 A(C R)$ and $3 B(M G)$ show plots of experimental data fitted to the pseudo-second-order rate model. Table 2 gives the parameters determined from the linear regression plots $\left(t / q_{\mathrm{t}}\right.$ vs. $\left.t\right)$ using the pseudo-second-order model and the experimental values of $q_{\mathrm{e}}\left(q_{\mathrm{e}, \mathrm{exp}}\right)$ for both dyes. 
Table 1. Fungal biomass used for removal of Congo red and malachite green.

\begin{tabular}{|c|c|c|c|c|c|c|}
\hline Fungal Strain & Adsorbate & $\begin{array}{l}\text { Operational } \\
\text { Conditions }\end{array}$ & $\begin{array}{c}\text { Adsorbate } \\
\text { Concentration } \\
\left(\mathrm{mg} \mathrm{L}^{-1}\right)\end{array}$ & $\begin{array}{l}\text { Adsorption } \\
\text { Capacity } \\
\left(\mathrm{mg} \mathrm{g}^{-1}\right)\end{array}$ & Removal (\%) & Ref. \\
\hline Aspergillus fumigatus & $\mathrm{CR}$ & $\begin{array}{l}\text { Dead fungus biomass, } \\
\text { pH: } 6,180 \mathrm{~min}, 25^{\circ} \mathrm{C} \text {. }\end{array}$ & 100 & $\mathrm{Nm}$ & 78 & [65] \\
\hline Aspergillus niger & $\mathrm{CR}$ & $\begin{array}{l}0.2 \mathrm{~g} \text { of dry fungal } \\
\text { biomass, } \mathrm{pH}: 6.0,42 \mathrm{~h} \text {. }\end{array}$ & 50 & 14.7 & 89.6 & [56] \\
\hline $\begin{array}{l}\text { Aspergillus niger } \\
\text { ZJUBE-1 }\end{array}$ & $\mathrm{CR}$ & $\begin{array}{l}\mathrm{pH}: 2-5 ; 120 \mathrm{rpm} \text {, } \\
28^{\circ} \mathrm{C} \text {, mycelial pellets } \\
\left(4 \mathrm{~g} \mathrm{~L}^{-1}\right), 12 \mathrm{~h} .\end{array}$ & $25-300$ & 263.2 & 99 & [66] \\
\hline $\begin{array}{l}\text { Phanerochaete } \\
\text { chrysosporium }\end{array}$ & CR & Mycelial pellets, $48 \mathrm{~h}$. & 500 & $\mathrm{Nm}$ & 90 & [67] \\
\hline Trametes versicolor & $\mathrm{CR}$ & $\begin{array}{l}\mathrm{pH}: 2 \text {, sterilized } \\
\text { biomass. }\end{array}$ & 50 & 51.8 & 90 & [58] \\
\hline Pleurotus ostreatus & MG & $\begin{array}{l}\mathrm{pH}: 2 \text { to } 10,180 \mathrm{~min}, 25 \\
{ }^{\circ} \mathrm{C} \text {. }\end{array}$ & 40 & 32.3 & 89.6 & [68] \\
\hline Trichoderma asperellum & MG & $\begin{array}{l}\text { pH: } 5 \text {, immobilized } \\
\text { biomass, } 30^{\circ} \mathrm{C}, 200 \\
\text { rpm. }\end{array}$ & 100 & 50.3 & $\mathrm{Nm}$ & [31] \\
\hline Trichoderma asperellum & MG & $\begin{array}{l}2 \mathrm{~g} \text { of the freshly } \\
\text { prepared fungal } \\
\text { biomass, } 14 \text { days, } 150 \\
\mathrm{rpm}, 30^{\circ} \mathrm{C} \text {. }\end{array}$ & 100 & $\mathrm{Nm}$ & 62 & [69] \\
\hline $\begin{array}{l}\text { Penicillium } \\
\text { simplicissimum }\end{array}$ & MG & $\begin{array}{l}2 \mathrm{~g} \text { of the freshly } \\
\text { prepared fungal } \\
\text { biomass, } 14 \text { days, } 150 \\
\text { rpm, } 30^{\circ} \mathrm{C} \text {. }\end{array}$ & 100 & $\mathrm{Nm}$ & 54 & [70] \\
\hline Coriolopsis sp. & MG & $\begin{array}{l}2 \mathrm{~g} \text { of the freshly } \\
\text { prepared fungal } \\
\text { biomass, } 14 \text { days, } 150 \\
\mathrm{rpm}, 30^{\circ} \mathrm{C} \text {. }\end{array}$ & 100 & $\mathrm{Nm}$ & 52 & [71] \\
\hline Penicillium ochrochloron & MG & $\begin{array}{l}0.3 \mathrm{~g} \text { of the freshly } \\
\text { prepared fungal } \\
\text { biomass, } 10 \text { days, } \mathrm{pH}: 7 \text {, } \\
30^{\circ} \mathrm{C} \text {. }\end{array}$ & 50 & $\mathrm{Nm}$ & 93 & [72] \\
\hline $\begin{array}{l}\text { Penicillium } \\
\text { simplicissimum }\end{array}$ & MG & $\begin{array}{l}0.8 \mathrm{~g} \text { of the freshly } \\
\text { prepared fungal } \\
\text { biomass, } 480 \mathrm{~min}, \mathrm{pH}: 5 \text {, } \\
2^{\circ} \mathrm{C} \text {. }\end{array}$ & 50 & $\mathrm{Nm}$ & 88.5 & [61] \\
\hline $\begin{array}{l}\text { Penicillium } \\
\text { simplicissimum }\end{array}$ & MG & $\begin{array}{l}0.1 \mathrm{~g} \text { of dry fungal } \\
\text { biomass, } 480 \mathrm{~min}, \mathrm{pH} 5, \\
2{ }^{\circ} \mathrm{C} \text {. }\end{array}$ & 50 & $\mathrm{Nm}$ & 56.9 & [61] \\
\hline
\end{tabular}

$\mathrm{Nm}=$ No mentioned .
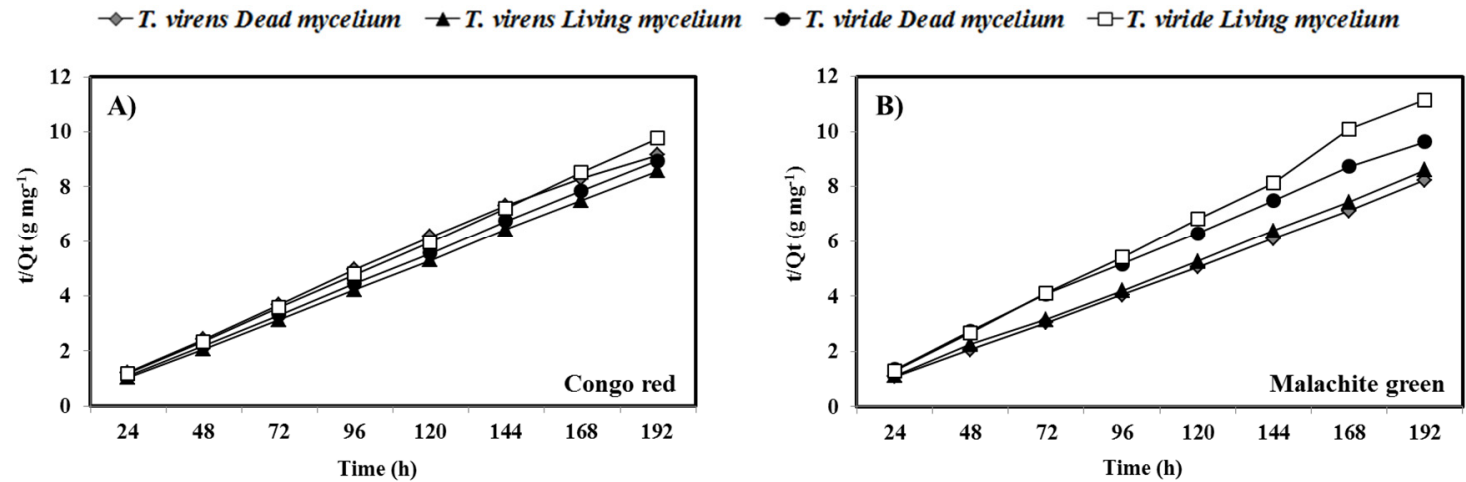

Figure 3. Pseudo-second-order model plot for fungal fresh biomass. (A) Congo red and (B) malachite green. Lines are guides to the eyes. 
Table 2. Pseudo-second-order kinetic parameters for the removal of Congo red and malachite green by fungal fresh biomass of T. virens and T. viride.

\begin{tabular}{|c|c|c|c|c|c|}
\hline Adsorbent & Dye & $K_{2}\left(g g^{-1} h^{-1}\right)$ & $q_{\mathrm{e}}\left(\mathrm{mg} \mathrm{g}^{-1}\right)$ & $q_{\exp }\left(\mathrm{mg} \mathrm{g}^{-1}\right)$ & $\mathbf{R}^{2}$ \\
\hline T. virens dead mycelium & CR & -0.0234 & 22.15 & 23.39 & 0.999 \\
\hline T. virens living mycelium & CR & 0.0116 & 20.74 & 21.97 & 0.998 \\
\hline T. viride dead mycelium & CR & -0.0422 & 21.28 & 22.44 & 0.999 \\
\hline T. viride living mycelium & CR & -0.0275 & 19.56 & 20.65 & 0.999 \\
\hline T. virens dead mycelium & MG & 0.0543 & 22.66 & 23.36 & 0.999 \\
\hline T. virens living mycelium & MG & 0.1062 & 23.60 & 22.36 & 0.999 \\
\hline T. viride dead mycelium & MG & 0.0067 & 20.29 & 18.64 & 0.998 \\
\hline T. viride living mycelium & MG & -0.0181 & 16.87 & 17.62 & 0.998 \\
\hline
\end{tabular}

3.2. Removal of $C R$ and $M G$ by Activated Carbon and Dry Biomass of T. virens and T. viride

Figure 4 shows removal efficiencies for $C R$ (Figure $4 \mathrm{~A}$ ) and MG (Figure $4 \mathrm{~B}$ ), for the more representative dye concentrations, as a function of stirring times ranging from 1.5 to $48 \mathrm{~h}$. It is important to note that removal by activated carbon is very fast for both dyes and remained almost unchanged during the experimentation time, indicating that it reaches the equilibrium faster than the mycelium of both Trichoderma isolates. As it can be seen, during the first $24 \mathrm{~h}$, the activated carbon showed the highest $\mathrm{CR}$ removal capacity. In absorption processes, activated carbon is a highly effective and versatile material. However, both chemical and thermal regeneration of the used carbon produces effluent, is expensive, and is impractical on a large scale.
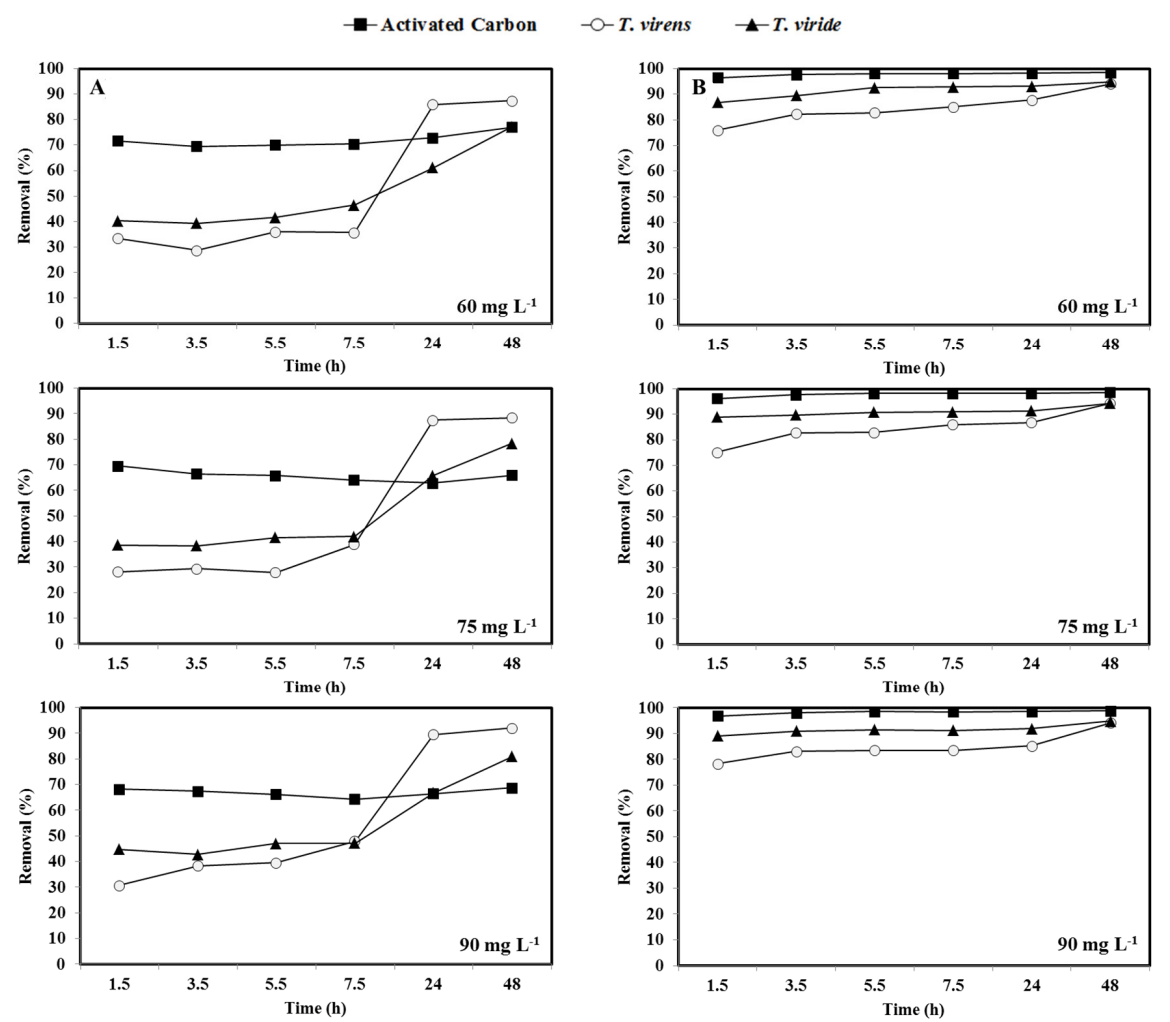

Figure 4. Removal efficiency of Congo red (row A) and malachite green (row B) $\left(60,75\right.$, and $90 \mathrm{mg} \mathrm{L}^{-1}$ ) by activated carbon and fungal dry biomass of T. virens and T. viride.

On the other hand, after $24 \mathrm{~h}$, the dry biomass of both Trichoderma species showed higher CR removal capacity than activated carbon (Figure $4 \mathrm{~A}$ ). In addition, the $\mathrm{CR}$ removal obtained by the dry biomass of $T$. virens $(88 \%)$ was higher than that reported for the fungus Aspergillus niger (72\%) [73]. In contrast, MG removal by the dry biomass of both fungi was lower than that observed by activated carbon during the first $24 \mathrm{~h}$, although, at $48 \mathrm{~h}$, the 
removal of MG by the dry fungal biomass was similar to that observed for activated carbon (Figure 4B).

Equilibrium adsorptions data of CR and MG onto activated carbon and dry biomass of the two Trichoderma species were analyzed using the Freundlich (Equation (2)) and Langmuir (Equation (3)) adsorption isotherms. The isothermal plots were found to be linear, and the linear correlation coefficients were slightly higher for the Langmuir model (Figure 5); all the calculated isotherm model parameters are given in Table 2.
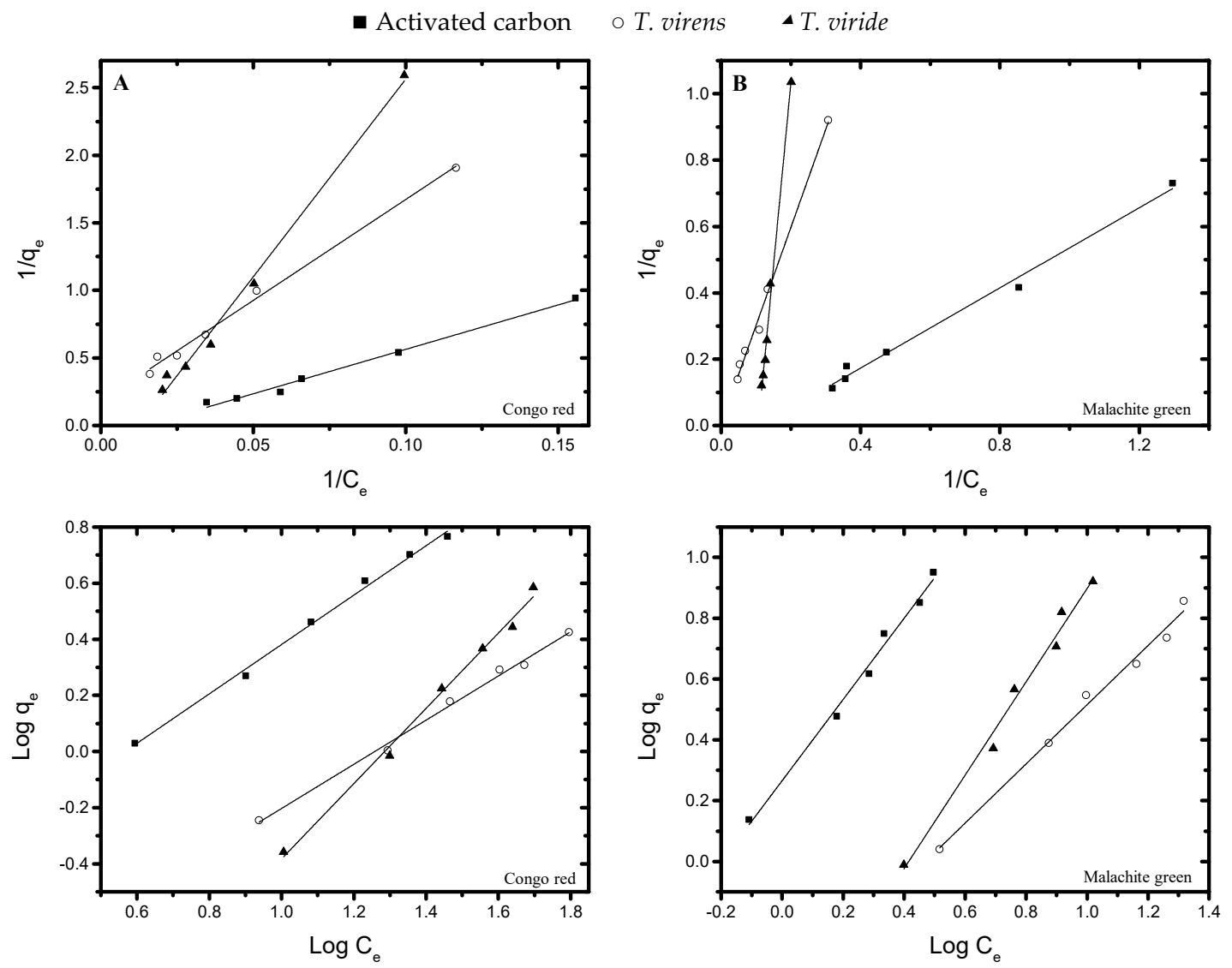

Figure 5. Linear Freundlich (Equation (2)) and Langmuir (Equation (3)) adsorption isotherm for Congo red (row A) and malachite green (row B).

Additionally, we calculate the equilibrium parameter, $R_{\mathrm{L}}$, which represent an important characteristic in the Langmuir model and is defined by

$$
R_{\mathrm{L}}=\frac{1}{1+K_{\mathrm{L}} C_{0}}
$$

where $C_{0}$ stands for the initial concentration of dye. The value of $R_{\mathrm{L}}$ indicates favorable absorption if $0<R_{\mathrm{L}}<1$. In addition, $R_{\mathrm{L}}=0$ denotes irreversible absorption, $R_{\mathrm{L}}=1$ indicates linear absorption, and $R_{\mathrm{L}}>1$ reveals unfavorable absorption [74]. Then, higher correlation coefficients for the Langmuir model and $R_{\mathrm{L}}$ values between 0 and 1 (last column in Table 3) suggest that the adsorption of $C R$ and $M G$ by activated carbon and dry biomass of $T$. virens and T. viride could be well described by the Lamgmuir model.

Parameters found through the Freundlich model could give information about the heterogeneous nature of adsorption $(n>1)$. That is the case of CR adsorption by activated carbon and T. virens, and MG adsorption by T. virens. However, linear correlation coefficients $\left(\mathrm{R}^{2}\right)$ are higher for the Langmuir model than for the Freundlich model. 
Table 3. Langmuir and Freundlich adsorption isotherm parameters. Initial concentrations $\left(C_{0}\right)$ of dye, $15 \mathrm{mg} / \mathrm{L}$.

\begin{tabular}{|c|c|c|c|c|c|c|c|c|}
\hline Dye & Adsorbent & $\begin{array}{c}\text { Freundlich } \\
K_{\mathrm{F}}\left(\left(\mathrm{mg} \mathrm{g}^{-1}\right) /\right. \\
\left.\left(\mathrm{mg} \mathrm{L}^{-1}\right)^{1 / \mathrm{n}}\right)\end{array}$ & $\mathbf{n}$ & $\mathbf{R}^{2}$ & $\begin{array}{c}\text { Langmuir } \\
q_{\mathrm{m}}\left(\mathrm{mg} \mathrm{g}^{-1}\right)\end{array}$ & $K_{\mathrm{L}}\left(\mathrm{L} \mathrm{mg}^{-1}\right)$ & $\mathbf{R}^{2}$ & $R_{\mathrm{L}}$ \\
\hline \multirow[t]{3}{*}{$\mathrm{CR}$} & Activated carbon & 0.317 & 1.136 & 0.991 & 10.684 & 0.014 & 0.996 & 0.44 \\
\hline & T.virens & 0.102 & 1.270 & 0.990 & 5.577 & 0.012 & 0.995 & 0.48 \\
\hline & T. viride & 0.019 & 0.746 & 0.989 & 2.764 & 0.012 & 0.993 & 0.48 \\
\hline \multirow[t]{3}{*}{ MG } & Activated carbon & 1.843 & 0.749 & 0.991 & 14.514 & 0.114 & 0.993 & 0.88 \\
\hline & T.virens & 0.348 & 1.027 & 0.991 & 81.818 & 0.002 & 0.994 & 0.84 \\
\hline & T. viride & 0.231 & 0.652 & 0.986 & 0.848 & 0.107 & 0.995 & 0.09 \\
\hline
\end{tabular}

For the Langmuir isotherm, the saturation capacity of the monolayer in the activated carbon (10.7) is greater than that for T. virens (5.6) and T. viride (2.76), for CR; whereas for the MG dye, T. virens (81.8) had higher saturation capacity of the monolayer when compared to $T$. viride and activated carbon. The constant $K_{\mathrm{L}}$ for $\mathrm{CR}$ dye had similar values in all three adsorbent materials, whereas for $\mathrm{MG}$, the $K_{\mathrm{L}}$ was greater for activated carbon (Table 3).

Reviewing the reports for the monolayer saturation capacity of other organic and inorganic adsorbents used for the removal of CR dye (Table 4), it was found that most of the materials showed a higher saturation capacity of the monolayer than that obtained for the two species of Trichoderma reported in this study: straw carbon (403.7), grapefruit peel carbon (169.5), ground nut shells charcoal (117.6), bamboo dust carbon (101.9), Ca-bentonite (85.3), hen feather (73.8), and cassava residue (59.2), among others. Nevertheless, the saturation capacity was higher than that reported for other adsorbents such as laboratory-grade activated carbon and commercial-grade activated carbon, with 1.88 and 0.64, respectively [75-77]. On the other hand, for MG, few materials showed higher saturation capacity of the monolayer than T. virens (Table 4): tobacco hairy roots (277.2), coco-peat (276.8), Anethum graveolens (244.0), brown alga Dictyota cervicornis (230.0), oil palm trunk fiber (149.4), and magnetic bacterial cellulose (270.3). Finally, it is worth noting the performance of the Ackee apple seed-bentonite composite, which showed the highest saturation capacity for both CR (1439.9) and MG (706.7). Thus, an alternative to improve the adsorption capacity of dry biomass of $T$. virens is to apply an acid or alkaline pre-treatment or combine it with other materials or biomasses from other fungi or microorganisms.

On the other hand, the kinetics studies reveal that adsorption rates of CR and MG by activated carbon and dry biomass of $T$. virens and $T$. viride are adequately described by the pseudo-second-order rate model (Figure 6). Table 5 shows the values obtained from the linear regression plots $\left(t / q_{\mathrm{t}} \mathrm{vs}\right.$. $\left.t\right)$ using the pseudo-second-order model, for the different concentrations of both dyes, finding that $q_{\mathrm{e}}$ tends to increase along with $C_{\mathrm{e}}$ in the three adsorbents tested in this study; the highest values of $q_{\mathrm{e}}$ were obtained with activated carbon. 
Table 4. Organic and inorganic adsorbents used for the removal of Congo red and malachite green dyes.

\begin{tabular}{|c|c|c|c|c|c|c|}
\hline Material & Adsorbate & $\begin{array}{c}\text { Adsorption } \\
\text { Capacity } \\
\left(\mathrm{mg} \mathrm{g}^{-1}\right)\end{array}$ & $\begin{array}{c}\text { Concentration } \\
\text { Range } \\
\left(\mathrm{mg} \mathrm{L}^{-1}\right)\end{array}$ & $\begin{array}{l}\text { Contact } \\
\text { Time }\end{array}$ & $\mathrm{pH}$ & Ref. \\
\hline Banana peel & CR & 18.2 & $10-120$ & $24 \mathrm{~h}$ & $\mathrm{Nm}$ & [78] \\
\hline Orange peel & CR & 14.0 & $10-120$ & $24 \mathrm{~h}$ & $\mathrm{Nm}$ & [78] \\
\hline Activated red mud & CR & 7.0 & $10-90$ & $90 \mathrm{~min}$ & $\mathrm{Nm}$ & [79] \\
\hline Chitosan & $\mathrm{CR}$ & 81.2 & NP & $12 \mathrm{~h}$ & 7 & [80] \\
\hline Sunflower stalk & CR & 37.8 & 50-1000 & $5 \mathrm{~d}$ & $\mathrm{Nm}$ & [81] \\
\hline Coir pith & $\mathrm{CR}$ & 6.7 & $20-80$ & $\mathrm{Nm}$ & 7.7 & [82] \\
\hline Ca-bentonite & CR & 85.3 & 50-200 & $600 \mathrm{~min}$ & $5-10$ & [83] \\
\hline Straw carbon & CR & 403.7 & 175 & $120 \mathrm{~min}$ & 7.4 & [84] \\
\hline $\begin{array}{l}\text { Grapefruit peel } \\
\text { carbon }\end{array}$ & $\mathrm{CR}$ & 169.5 & $\mathrm{Nm}$ & $120 \mathrm{~min}$ & 3 & [85] \\
\hline $\begin{array}{c}\text { Ground nut shells } \\
\text { charcoal }\end{array}$ & $\mathrm{CR}$ & 117.6 & 65 & $60 \mathrm{~min}$ & 7 & [86] \\
\hline $\begin{array}{l}\text { Bamboo dust } \\
\text { carbon }\end{array}$ & $\mathrm{CR}$ & 101.9 & 150 & $120 \mathrm{~min}$ & 7.4 & [84] \\
\hline Hen feather & CR & 73.8 & 6.96 & $3 \mathrm{~h}$ & 7.0 & [87] \\
\hline Cassava residue & CR & 59.2 & 100 & $240 \mathrm{~min}$ & 8.5 & [88] \\
\hline Cattail root & $\mathrm{CR}$ & 38.8 & 50 & $360 \mathrm{~min}$ & 7.0 & [89] \\
\hline $\begin{array}{c}\text { Ackee apple } \\
\text { seed-bentonite } \\
\text { composite }\end{array}$ & $\mathrm{CR}$ & 1439.9 & $100-6000$ & $480 \min$ & $2-10$ & [90] \\
\hline $\begin{array}{l}\text { Oil palm trunk } \\
\text { fiber }\end{array}$ & MG & 149.4 & $25-300$ & $120 \mathrm{~min}$ & $\mathrm{Nm}$ & [91] \\
\hline $\begin{array}{l}\text { Waste material } \\
\text { from paper } \\
\text { industry, pine bark }\end{array}$ & MG & $\mathrm{Nm}$ & 100 & $1 \mathrm{~h}$ & $\mathrm{Nm}$ & [92] \\
\hline $\begin{array}{c}\text { Carbonaceous } \\
\text { material }\end{array}$ & MG & 75.1 & 36.49 & $6-8 \mathrm{~h}$ & $\mathrm{Nm}$ & [93] \\
\hline Sugarcane dust & MG & 3.9 & 12 & $30 \mathrm{~min}$ & $\mathrm{Nm}$ & [94] \\
\hline Neem sawdust & MG & 4.4 & 6-12 & $24 \mathrm{~min}$ & 7.2 & [95] \\
\hline $\begin{array}{l}\text { Apricot stones } \\
\text { Ackee apple }\end{array}$ & MG & 23.8 & $4.45-17.6$ & $60 \mathrm{~min}$ & $3-11$ & [96] \\
\hline $\begin{array}{l}\text { seed-bentonite } \\
\text { composite }\end{array}$ & MG & 706.7 & $100-6000$ & $480 \mathrm{~min}$ & $2-10$ & [90] \\
\hline Rattan sawdust & MG & 62.7 & $25-300$ & $210 \mathrm{~min}$ & $2-12$ & [97] \\
\hline Bentonite & MG & 178.6 & $50-300$ & $2 \mathrm{~h}$ & $3-11$ & [98] \\
\hline $\begin{array}{c}\text { Magnetic bacterial } \\
\text { cellulose } \\
\text { nanofiber/graphene } \\
\text { oxide polymer } \\
\text { aerogel }\end{array}$ & MG & 270.3 & $5-50$ & $5-25 \mathrm{~min}$ & $2-12$ & [99] \\
\hline $\begin{array}{c}\text { Carbonized } \\
\text { pomegranate peel }\end{array}$ & MG & 31.5 & 30 & $1-150 \mathrm{~min}$ & 6 & [100] \\
\hline Coco-peat & MG & 276.8 & 500 & $2-240 \mathrm{~min}$ & 7 & [101] \\
\hline $\begin{array}{c}\text { Brown alga } \\
\text { Dictyota cervicornis }\end{array}$ & MG & 230 & $5-125$ & $10-2440$ & $3-11$ & [102] \\
\hline Tobacco hairy roots & MG & 277.2 & 50-100 & $0-120$ & $3-7$ & [103] \\
\hline Anethum graveolens & MG & 244 & $10-50$ & $20 \mathrm{~min}$ & $3-10$ & [104] \\
\hline
\end{tabular}



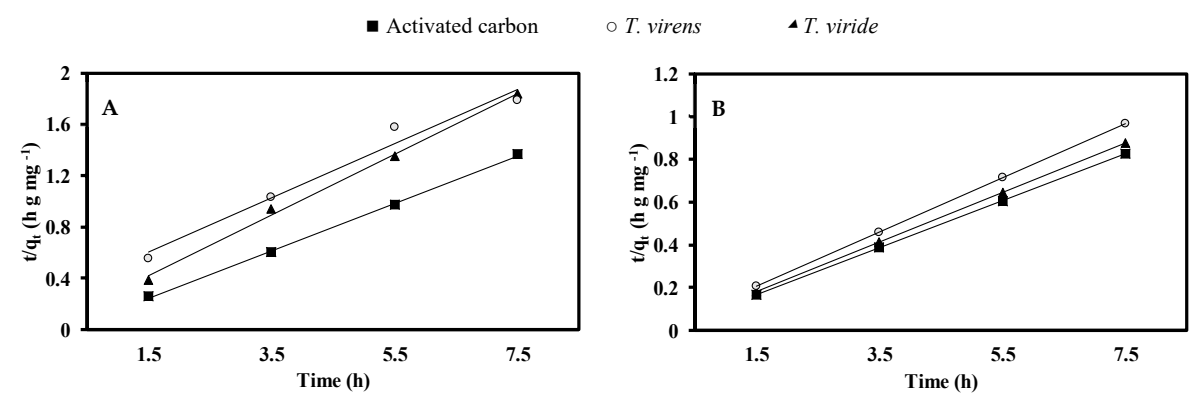

Figure 6. Pseudo-second-order model fit plot for activated carbon and fungal dry biomass of T. virens and T. viride. (A) Congo red and (B) malachite green.

Table 5. Pseudo-second-order kinetic parameters for the removal of Congo red and malachite green by fungal dry biomass of T. virens and T. viride.

\begin{tabular}{|c|c|c|c|c|c|}
\hline Dye & Concentration $\left(\mathrm{mg} \mathrm{L}^{-1}\right)$ & Adsorbent & $q_{\mathrm{e}}\left(\mathrm{mg} \mathrm{g}^{-1}\right)$ & $K_{2}\left(g \mathrm{mg}^{-1} \mathrm{~h}^{-1}\right)$ & $\mathbf{R}^{2}$ \\
\hline $\mathrm{CR}$ & 15 & Activated carbon & 0.525 & 6.819 & 0.999 \\
\hline CR & 15 & T. virens & 0.297 & 11.952 & 0.985 \\
\hline CR & 15 & T. viride & 0.209 & 10.381 & 0.991 \\
\hline MG & 15 & Activated carbon & 0.700 & 6.215 & 1.000 \\
\hline MG & 15 & T. virens & 0.625 & 10.368 & 0.999 \\
\hline MG & 15 & T. viride & 0.619 & 3.505 & 0.999 \\
\hline CR & 30 & Activated carbon & 0.900 & 3.691 & 0.999 \\
\hline CR & 30 & T. virens & 0.388 & 6.249 & 0.999 \\
\hline CR & 30 & T. viride & 0.600 & 7.030 & 0.991 \\
\hline MG & 30 & Activated carbon & 1.548 & 2.773 & 1.000 \\
\hline MG & 30 & T. virens & 1.425 & 4.870 & 0.999 \\
\hline MG & 30 & T. viride & 1.458 & 10.890 & 0.999 \\
\hline CR & 45 & Activated carbon & 1.592 & 3.022 & 0.999 \\
\hline $\mathrm{CR}$ & 45 & T. virens & 0.813 & 5.943 & 0.999 \\
\hline CR & 45 & T. viride & 0.908 & 9.418 & 0.988 \\
\hline MG & 45 & Activated carbon & 2.168 & 2.058 & 1.000 \\
\hline MG & 45 & T. virens & 2.006 & 2.982 & 0.999 \\
\hline MG & 45 & T. viride & 2.076 & 2.678 & 0.999 \\
\hline $\mathrm{CR}$ & 60 & Activated carbon & 1.986 & 2.002 & 0.999 \\
\hline$C R$ & 60 & T. virens & 1.160 & 3.389 & 0.986 \\
\hline CR & 60 & T. viride & 1.247 & 4.831 & 0.999 \\
\hline MG & 60 & Activated carbon & 2.875 & 1.486 & 1.000 \\
\hline MG & 60 & T. virens & 2.583 & 2.904 & 0.999 \\
\hline MG & 60 & T. viride & 2.796 & 2.090 & 0.999 \\
\hline $\mathrm{CR}$ & 75 & Activated carbon & 2.296 & 1.300 & 0.999 \\
\hline $\mathrm{CR}$ & 75 & T. virens & 1.060 & 3.709 & 0.998 \\
\hline CR & 75 & T. viride & 1.598 & 5.921 & 0.999 \\
\hline MG & 75 & Activated carbon & 3.644 & 1.191 & 1.000 \\
\hline MG & 75 & T. virens & 3.206 & 2.828 & 0.999 \\
\hline MG & 75 & T. viride & 3.399 & 1.315 & 1.000 \\
\hline CR & 90 & Activated carbon & 2.716 & 1.121 & 0.999 \\
\hline$C R$ & 90 & T. virens & 2.207 & 1.561 & 0.988 \\
\hline CR & 90 & T. viride & 2.108 & 3.926 & 0.997 \\
\hline MG & 90 & Activated carbon & 4.570 & 0.941 & 1.000 \\
\hline MG & 90 & T. virens & 3.951 & 1.408 & 1.000 \\
\hline MG & 90 & T. viride & 4.322 & 1.042 & 1.000 \\
\hline
\end{tabular}

\section{Conclusions}

The removal of dyes depends on physicochemical factors such as the concentration and size of the dye molecule, ionic charge, $\mathrm{pH}$, and temperature. In this research, it was observed that the genotype and the preparation of the fungal biomass are relevant factors when looking for high removal percentages. In that sense, it was found that the removal of CR by the fresh biomass of both species of Trichoderma studied was very similar. For MG, the highest percentage of removal was obtained with the live and dead biomass of $T$. virens.

In the same way, the present study showed that after $24 \mathrm{~h}$ of contact time, fresh and dry biomass of $T$. virens and $T$. viride had a higher $C R$ removal capacity than activated carbon. Additionally, T. virens showed a higher saturation capacity of the monolayer than 
T. viride and activated carbon for MG removal. Thus, either fresh or dry biomass of T. virens can represent a simple and cost-effective alternative for removing industrial dyes like CR and MG.

Author Contributions: Conceptualization, R.A.-D. and M.J.G.-M.; methodology, R.A.-D.; investigation and formal analysis, R.A.-D.; M.J.G.-M. and R.U.-K.; data curation, R.A.-D., M.J.G.-M. and R.U.-K. writing-original draft preparation, R.A.-D. and M.J.G.-M.; writing—review and editing, R.A.-D.; M.J.G.-M. and R.U.-K.; funding acquisition, R.A.-D. All authors have read and agreed to the published version of the manuscript.

Funding: This research was funded by Consejo Nacional de Ciencia y Tecnología-CONACYT of Mexico, from the Basic Science Project-SEP, grant number 239601.

Institutional Review Board Statement: Not applicable.

Informed Consent Statement: Not applicable.

Data Availability Statement: Data available in a publicly accessible repository.

Acknowledgments: Thanks to the Unit of Support Services in Analytical Resolution of the Universidad Veracruzana.

Conflicts of Interest: The authors declare no conflict of interest.

\section{References}

1. Mathur, N.; Bhatnagar, P.; Sharma, P. Review of the Mutagenicity of Textile Dye Products. Univ. J. Environ. 2012, 2, 1-18.

2. Shaban, M.; Abukhadra, M.R.; Shahien, M.G.; Ibrahim, S.S. Novel bentonite/zeolite-NaP composite efficiently removes methylene blue and Congo red dyes. Environ. Chem. Lett. 2018, 16, 275-280. [CrossRef]

3. Kaushik, P.; Malik, A. Fungal dye decolourization: Recent advances and future potential. Environ. Int. 2009, 35, $127-141$. [CrossRef] [PubMed]

4. Siddiqui, S.I.; Rathi, G.; Chaudhry, S.A. Acid washed black cumin seed powder preparation for adsorption of methylene blue dye from aqueous solution: Thermodynamic, kinetic and isotherm studies. J. Mol. Liq. 2018, 264, 275-284. [CrossRef]

5. Ansari, R.; Mosayebzadeh, Z. Application of polyaniline as an efficient and novel adsorbent for azo dyes removal from textile wastewaters. Chem. Pap. 2011, 65, 1-8. [CrossRef]

6. Hunger, K. (Ed.) Industrial Dyes: Chemistry, Properties, Applications, 1st ed.; WILEY-VCH: Weinheim, Germany, 2003 ; pp. 1-12.

7. Steensma, D.P. “Congo" Red Out of Africa? Arch. Pathol. Lab. Med. 2001, 125, 250-252. [PubMed]

8. Jalandoni-Buan, A.C.; Lynn, A.; Decena-Soliven, A.; Cao, E.P.; Barraquio, V.L.; Barraquio, W.L. Congo Red Decolorizing Activity Under Microcosm and Decolorization of other Dyes by Congo Red Decolorizing Bacteria. Philipp. J. Sci. 2009, 138, 125-132.

9. Alderman, D.J. Malachite green: A review. J. Fish. Dis. 1985, 8, 289-298. [CrossRef]

10. Raval, N.P.; Shah, P.U.; Shah, N.K. Malachite green "A cationic dye" and its removal from aqueous solution by adsorption. Appl. Water Sci. 2017, 7, 3407-3445. [CrossRef]

11. Knapp, J.S.; Bromley-Challenor, K.C.A. Recalcitrant organic compounds. In Handbook of Water and Wastewater Microbiology; Mara, D., Horan, N.J., Eds.; Academic: San Diego, CA, USA, 2003; pp. 559-596.

12. Madsen, E.L. Biodegradability of recalcitrant aromatic compounds. In Comprehensive Biotechnology, 2nd ed.; Murray, M.Y., Ed.; Academic Press: Burlington, NJ, USA, 2011; pp. 95-103.

13. Fewson, C.A. Biodegradation of xenobiotic and other persistent compounds: The causes of recalcitrance. Trends Biotechnol. 1988, 6, 148-153. [CrossRef]

14. DeVito, S.C. Predicting Azo Dye Toxicity. Crit. Rev. Environ. Sci. Technol. 1993, 23, $249-324$.

15. Srivastava, S.; Sinha, R.; Roy, D. Toxicological effects of malachite green. Aquat. Toxicol. 2004, 66, 319-329. [CrossRef] [PubMed]

16. Tara, N.; Siddiqui, S.I.; Rathi, G.; Chaudhry, S.A.; Inamuddin; Asiri, A.M. Nano-engineered Adsorbent for the Removal of Dyes from Water: A Review. Curr. Anal. Chem. 2019, 16, 14-40. [CrossRef]

17. Salleh, M.A.M.; Mahmoud, D.K.; Karim, W.A.; Idris, A. Cationic and anionic dye adsorption by agricultural solid wastes: A comprehensive review. Desalination 2011, 280, 1-13. [CrossRef]

18. Chanzu, H.A.; Onyari, J.M.; Shiundu, P.M. Brewers' spent grain in adsorption of aqueous Congo Red and malachite Green dyes: Batch and continuous flow systems. J. Hazard. Mater. 2019, 380,1-8. [CrossRef] [PubMed]

19. Bhatia, D.; Sharma, N.R.; Singh, J.; Kanwar, R.S. Biological methods for textile dye removal from wastewater: A review. Crit. Rev. Environ. Sci. Technol. 2017, 47, 1836-1876. [CrossRef]

20. Waghmode, T.R.; Kurade, M.B.; Sapkal, R.T.; Bhosale, C.H.; Jeon, B.H.; Govindwar, S.P. Sequential photocatalysis and biological treatment for the enhanced degradation of the persistent azo dye methyl red. J. Hazard. Mater. 2019, 371, 115-122. [CrossRef]

21. Jafari, N.; Soudi, M.R.; Kasra-Kermanshahi, R. Biodegradation perspectives of azo dyes by yeasts. Microbiology 2014, 83, 484-497. [CrossRef] 
22. Yagub, M.T.; Sen, T.K.; Afroze, S.; Ang, H.M. Dye and its removal from aqueous solution by adsorption: A review. Adv. Colloid Interface Sci. 2014, 209, 172-184. [CrossRef]

23. Katheresan, V.; Kansedo, J.; Lau, S.Y. Efficiency of various recent wastewater dye removal methods: A review. J. Environ. Chem. Eng. 2018, 6, 4676-4697. [CrossRef]

24. Fomina, M.; Gadd, G.M. Biosorption: Current perspectives on concept, definition and application. Bioresour. Technol. 2014, 160, 3-14. [CrossRef] [PubMed]

25. Crini, G. Non-conventional low-cost adsorbents for dye removal: A review. Bioresour. Technol. 2006, 97, 1061-1085. [CrossRef] [PubMed]

26. Aksu, Z. Application of biosorption for the removal of organic pollutants: A review. Process. Biochem. 2005, 40, 997-1026. [CrossRef]

27. Gadd, G.M. Biosorption: Critical review of scientific rationale, environmental importance and significance for pollution treatment. J. Chem. Technol. Biotechnol. 2009, 84, 13-28. [CrossRef]

28. Park, D.; Yun, Y.S.; Park, J.M. The past, present, and future trends of biosorption. Biotechnol. Bioprocess. Eng. 2010, 15, 86-102. [CrossRef]

29. Gupta, V.K.; Suhas. Application of low-cost adsorbents for dye removal-A review. J. Environ. Manag. 2009, 90, 2313-2342. [CrossRef]

30. Tigini, V.; Prigione, V.; Donelli, I.; Freddi, G.; Varese, G.C. Influence of culture medium on fungal biomass composition and biosorption effectiveness. Curr. Microbiol. 2012, 64, 50-59. [CrossRef]

31. Chew, S.Y.; Ting, A.S.Y. Common filamentous Trichoderma asperellum for effective removal of triphenylmethane dyes. Desalin. Water Treat. 2016, 57, 13534-13539. [CrossRef]

32. Aksu, Z.; Dönmez, G. A comparative study on the biosorption characteristics of some yeasts for remazol blue reactive dye. Chemosphere 2003, 50, 1075-1083. [CrossRef]

33. Kargi, F.; Ozmihci, S. Biosorption performance of powdered activated sludge for removal of different dyestuffs. Enzym. Microb. Technol. 2004, 35, 267-271. [CrossRef]

34. Kapdan, I.K.; Kargia, F.; McMullan, G.; Marchant, R. Effect of environmental conditions on biological decolorization of textile dyestuff by C. versicolor. Enzym. Microb. Technol. 2000, 26, 381-387. [CrossRef]

35. Cha, C.J.; Doerge, D.R.; Cerniglia, C.E. Biotransformation of Malachite Green by the Fungus Cunninghamella elegans. Appl. Environ. Microbiol. 2001, 67, 4358-4360. [CrossRef] [PubMed]

36. Aksu, Z. Reactive dye bioaccumulation by Saccharomyces cerevisiae. Process. Biochem. 2003, 38, 1437-1444. [CrossRef]

37. Pazarlioglu, N.K.; Urek, R.O.; Ergun, F. Biodecolourization of Direct Blue 15 by immobilized Phanerochaete chrysosporium. Process. Biochem. 2005, 40, 1923-1929. [CrossRef]

38. Aksu, Z.; Çağatay, Ş.Ş. Investigation of biosorption of Gemazol Turquise Blue-G reactive dye by dried Rhizopus arrhizus in batch and continuous systems. Sep. Purif. Technol. 2006, 48, 24-35. [CrossRef]

39. Aksu, Z.; Kiliç, N.K.; Ertuğrul, S.; Dönmez, G. Inhibitory effects of chromium(VI) and Remazol Black B on chromium(VI) and dyestuff removals by Trametes versicolor. Enzym. Microb. Technol. 2007, 40, 1167-1174. [CrossRef]

40. Matos, A.J.F.S.; Bezerra, R.M.F.; Dias, A.A. Screening of fungal isolates and properties of Ganoderma applanatum intended for olive mill wastewater decolourization and dephenolization. Lett. Appl. Microbiol. 2007, 45, 270-275. [CrossRef]

41. Zhao, X.; Hardin, I.R. HPLC and spectrophotometric analysis of biodegradation of azo dyes by Pleurotus ostreatus. Dye Pigments 2007, 73, 322-325. [CrossRef]

42. Sadhasivam, S.; Savitha, S.; Swaminathan, K. Redox-mediated decolorization of recalcitrant textile dyes by Trichoderma harzianum WL1 laccase. World J. Microbiol. Biotechnol. 2009, 25, 1733-1741. [CrossRef]

43. Sadhasivam, S.; Savitha, S.; Swaminathan, K. Feasibility of using Trichoderma harzianum biomass for the removal of erioglaucine from aqueous solution. World J. Microbiol. Biotechnol. 2007, 23, 1075-1081. [CrossRef]

44. Sadhasivam, S.; Saritha, E.; Savitha, S.; Swaminathan, K. Comparison of the efficacy of live and autoclaved mycelium of Trichoderma harzianum on the removal of trypan blue. Bull. Environ. Contam. Toxicol. 2005, 75, 1046-1053. [CrossRef] [PubMed]

45. Sadhasivam, S.; Savitha, S.; Swaminathan, K. Exploitation of Trichoderma harzianum mycelial waste for the removal of rhodamine 6G from aqueous solution. J. Environ. Manag. 2007, 85, 155-161. [CrossRef]

46. Sivasamy, A.; Sundarabal, N. Biosorption of an azo dye by Aspergillus niger and Trichoderma sp. fungal biomasses. Curr. Microbiol. 2011, 62, 351-357. [CrossRef] [PubMed]

47. Saeed, A.; Iqbal, M.; Zafar, S.I. Immobilization of Trichoderma viride for enhanced methylene blue biosorption: Batch and column studies. J. Hazard. Mater. 2009, 168, 406-415. [CrossRef] [PubMed]

48. Walsh, G.A.; Power, R.F.; Headon, D.R. Enzymes in the animal-feed industry. Trends Biotechnol. 1993, 11, 424-430. [CrossRef]

49. Buchert, J.; Ranua, M.; Siika-aho, M.; Pere, J.; Viikari, L. Trichoderma reesei cellulases in the bleaching of kraft pulp. Appl. Microbiol. Biotechnol. 1994, 40, 941-945. [CrossRef]

50. Rojo, F.G.; Reynoso, M.M.; Ferez, M.; Chulze, S.N.; Torres, A.M. Biological control by Trichoderma species of Fusarium solani causing peanut brown root rot under field conditions. Crop. Prot. 2007, 26, 549-555. [CrossRef]

51. Zhang, C.L.; Druzhinina, I.S.; Kubicek, C.P.; Xu, T. Trichoderma biodiversity in China: Evidence for a North to South distribution of species in East Asia. FEMS Microbiol. Lett. 2005, 251, 251-257. [CrossRef] 
52. Karthik, V.; Saravanan, K.; Patra, C.; Ushadevi, B.; Vairam, S.; Selvaraju, N. Biosorption of Acid Yellow 12 from simulated wastewater by non-viable T. harzianum: Kinetics, isotherm and thermodynamic studies. Int. J. Environ. Sci. Technol. 2019, 16, 6895-6906. [CrossRef]

53. Argumedo-Delira, R.; Alarcón, A.; Ferrera-Cerrato, R.; Almaraz, J.J.; Peña-Cabriales, J.J. Tolerance and growth of 11 Trichoderma strains to crude oil, naphthalene, phenanthrene and benzo[a]pyrene. J. Environ. Manag. 2012, 95, S291-S299. [CrossRef]

54. Ibarra-Medina, V.A.; Ferrera-Cerrato, R.; Alarcón, A.; Lara-Hernández, M.E.; Valdez-Carrasco, J.M. Isolation and screening of Trichoderma strains antagonistic to Sclerotinia sclerotiorum and Sclerotinia minor. Revista Mexicana de Micología 2010, $31,53-63$.

55. Wunch, K.G.; Feibelman, T.; Bennett, J.W. Screening for fungi capable of removing benzo[a]pyrene in culture. Appl. Microbiol. Biotechnol. 1997, 47, 620-624. [CrossRef]

56. Ali, N.; Hameed, A.; Ahmed, S.; Khan, A.G. Decolorization of structurally different textile dyes by Aspergillus niger SA1. World J. Microbiol. Biotechnol. 2008, 24, 1067-1072. [CrossRef]

57. Ramsay, J.A.; Nguyen, T. Decoloration of textile dyes by Trametes versicolor and its effect on dye toxicity. Biotechnol. Lett. 2002, 24, 1757-1761. [CrossRef]

58. Binupriya, A.R.; Sathishkumar, M.; Swaminathan, K.; Kuz, C.S.; Yun, S.E. Comparative studies on removal of Congo red by native and modified mycelial pellets of Trametes versicolor in various reactor modes. Bioresour. Technol. 2008, 99, 1080-1088. [CrossRef]

59. Bhattacharya, S.; Das, A.; Mangai, G.; Vignesh, K.; Sangeetha, J. Mycoremediation of Congo red dye by filamentous fungi. Braz. J. Microbiol. 2011, 42, 1526-1536. [CrossRef]

60. Moturi, B.; Singara Charya, M. Decolourisation of Crystal Violet and Malachite Green By fungi. Sci. World J. 2010, 4, 28-33. [CrossRef]

61. Chen, S.H.; Cheow, Y.L.; Ng, S.L.; Ting, A.S.Y. Removal of triphenylmethane dyes in single-dye and dye-metal mixtures by live and dead cells of metal-tolerant Penicillium simplicissimum. Sep. Sci. Technol. 2020, 55, 2410-2420. [CrossRef]

62. Kumhar, K.C.; Babu, A.; Bordoloi, M.; Ali, A. Evaluation of Culture Media for Biomass Production of Trichoderma viride (KBN 24) and Their Production Economics. AJAF 2015, 2, 317-320. [CrossRef]

63. Singh, A.; Shahid, M.; Srivastava, M.; Pandey, S.; Sharma, A.; Kumar, V. Optimal physical parameters for growth of Trichoderma species at varying $\mathrm{pH}$, temperature and agitation. Virol. Mycol. 2014, 3, 1.

64. Irshad, M.; Anwar, Z.; Mahmood, Z.; Aqil, T.; Mehmmod, S.; Nawaz, H. Bio-processing of agro-industrial waste orange peel for induced production of pectinase by Trichoderma viridi; its purification and characterization. Turk. J. Biochem. 2014, 39, 9-18. [CrossRef]

65. Abdel-Ghany, T.M.; Alawlaqi, M.M.; Shater, A.R.; Al Abboud, M.A. Congo red biosorption with live and dead biomass of thermophilic Aspergillus fumigates. Egypt. J. Exp. Biol. 2019, 15, 1-6. [CrossRef]

66. Lu, T.; Zhang, Q.; Yao, S. Efficient decolorization of dye-containing wastewater using mycelial pellets formed of marine-derived Aspergillus niger. Chin. J. Chem. Eng. 2017, 25, 330-337. [CrossRef]

67. Tatarko, M.; Bumpus, J.A. Biodegradation of Congo Red by Phanerochaete chrysosporium. Water Res. 1998, 32, 1713-1717. [CrossRef]

68. Chen, Z.; Deng, H.; Chen, C.; Yang, Y.; Xu, H. Biosorption of malachite green from aqueous solutions by Pleurotus ostreatus using Taguchi method. J. Environ. Health Sci. Eng. 2014, 12, 63. [CrossRef]

69. Marcharchand, S.; Ting, A.S.Y. Trichoderma asperellum cultured in reduced concentrations of synthetic medium retained dye decolourization efficacy. J. Environ. Manag. 2017, 203, 542-554. [CrossRef]

70. Chen, S.H.; Ting, A.S.Y. Biosorption and biodegradation potential of triphenylmethane dyes by newly discovered Penicillium simplicissimum isolated from indoor wastewater sample. Int. Biodeterior. Biodegrad. 2015, 103, 1-7. [CrossRef]

71. Chen, S.H.; Ting, A.S.Y. Biodecolorization and biodegradation potential of recalcitrant triphenylmethane dyes by Coriolopsis sp. isolated from compost. J. Environ. Manag. 2015, 150, 274-280. [CrossRef]

72. Shedbalkar, U.; Jadhav, J.P. Detoxification of malachite green and textile industrial effluent by Penicillium ochrochloron. Biotechnol. Bioprocess. Eng. 2011, 16, 196-204. [CrossRef]

73. Fu, Y.; Viraraghavan, T. Removal of Congo Red from an aqueous solution by fungus Aspergillus niger. Adv. Environ. Res. 2002, 7, 239-247. [CrossRef]

74. Bayramoglu, G.; Arica, M.Y. Adsorption of Congo Red dye by native amine and carboxyl modified biomass of Funalia trogii: Isotherms, kinetics and thermodynamics mechanisms. Korean J. Chem. Eng. 2018, 35, 1303-1311. [CrossRef]

75. Namasivayam, C.; Kanchana, N. Waste banana pith as adsorbent for color removal from wastewaters. Chemosphere 1992, 25, 1691-1705. [CrossRef]

76. Namasivayam, C.; Muniasamy, N.; Gayatri, K.; Rani, M.; Ranganathan, K. Removal of dyes from aqueous solutions by cellulosic waste orange peel. Bioresour. Technol. 1996, 57, 37-43. [CrossRef]

77. Mall, I.D.; Srivastava, V.C.; Agarwal, N.K.; Mishra, I.M. Removal of congo red from aqueous solution by bagasse fly ash and activated carbon: Kinetic study and equilibrium isotherm analyses. Chemosphere 2005, 61, 492-501. [CrossRef] [PubMed]

78. Annadurai, G.; Juang, R.S.; Lee, D.J. Use of cellulose-based wastes for adsorption of dyes from aqueous solutions. J. Hazard. Mater. 2002, 92, 263-274. [CrossRef]

79. Tor, A.; Cengeloglu, Y. Removal of congo red from aqueous solution by adsorption onto acid activated red mud. J. Hazard. Mater. 2006, 138, 409-415. [CrossRef] [PubMed]

80. Wang, L.; Wang, A. Adsorption characteristics of Congo Red onto the chitosan/montmorillonite nanocomposite. J. Hazard. Mater. 2007, 147, 979-985. [CrossRef] 
81. Sun, G.; Xu, X. Sunflower stalk as adsorbents for color removal from textile wastewater. Ind. Eng. Chem. Res. 1997, 36, 808-812. [CrossRef]

82. Namasivayam, C.; Kavitha, D. Removal of Congo red from water by adsorption on to activated carbon prepared from coir pith, an agricultural solid waste. Dyes Pigments 2002, 54, 47-58. [CrossRef]

83. Lian, L.; Guo, L.; Guo, C. Adsorption of Congo red from aqueous solutions onto Ca-bentonite. J. Hazard. Mater. 2009, 161, $126-131$. [CrossRef]

84. Kannan, N.; Meenakshisundaram, M. Adsorption of Congo red on various activated carbons. a comparative study. Water Air Soil Pollut. 2002, 138, 289-305. [CrossRef]

85. Huang, H.Y.; Luo, L.D.; Zhang, H.; Lu, Y.Q.; Zhang, D. Adsorption of Congo red from aqueous solutions by the activated carbons prepared from grapefruit peel. Appl. Mech. Mater. 2014, 529, 3-7. [CrossRef]

86. Kaur, H.; Thakur, A. Adsorption of Congo red dye from aqueous solution onto ash of Cassia fistula seeds: Kinetic and thermodynamic studies. Chem. Sci. Rev. Lett. 2014, 3, 159-169.

87. Mittal, A.; Thakur, V.; Mittal, J.; Vardhan, H. Process development for the removal of hazardous anionic azo dye Congo red from wastewater by using hen feather as potential adsorbent. Desalin. Water Treat. 2014, 52, 227-237. [CrossRef]

88. Li, H.X.; Zhang, R.J.; Tang, L.; Zhang, J.H.; Mao, Z.G. Use of cassava residue for the removal of Congo red from aqueous solution by a novel process incorporating adsorption and in vivo decolorization. BioResources 2014, 9, 6682-6698. [CrossRef]

89. Hu, Z.; Chen, H.; Ji, F.; Yuan, S. Removal of Congo Red from aqueous solution by cattail root. J. Hazard. Mater. 2010, 173, 292-297. [CrossRef]

90. Adebayo, M.A.; Adebomi, J.I.; Abe, T.O.; Areo, F.I. Removal of aqueous Congo red and malachite green using ackee apple seed-bentonite composite. Colloids Interface Sci. Commun. 2020, 38, 100311. [CrossRef]

91. Hameed, B.H.; El-Khaiary, M.I. Batch removal of malachite green from aqueous solutions by adsorption on oil palm trunk fibre: Equilibrium isotherms and kinetic studies. J. Hazard. Mater. 2008, 154, 237-244. [CrossRef]

92. Mendez, A.; Fernandez, F.; Gasco, G. Removal of malachite green using carbon-based adsorbents. Desalination 2007, 206, 147-153. [CrossRef]

93. Gupta, V.K.; Srivastava, S.K.; Mohan, D. Equilibrium uptake, sorption dynamics, process optimization, and column operations for the removal and recovery of malachite green from wastewater using activated carbon and activated slag. Ind. Eng. Chem. Res. 1997, 36, 2207-2218. [CrossRef]

94. Khattri, S.D.; Singh, M.K. Colour removal from dye wastewater using sugar cane dust as an adsorbent. Adsorpt. Sci. Technol. 1999, 17, 269-282. [CrossRef]

95. Khattria, S.D.; Singh, M.K. Removal of malachite green from dye wastewater using neem sawdust by adsorption. J. Hazard. Mater. 2009, 167, 1089-1094. [CrossRef] [PubMed]

96. Abbas, M. Experimental investigation of activated carbon prepared from apricot stones material (ASM) adsorbent for removal of malachite green (MG) from aqueous solution. Adsorpt. Sci. Technol. 2020, 38, 24-45. [CrossRef]

97. Hameed, B.H.; El-Khaiary, M.I. Malachite green adsorption by rattan sawdust: Isotherm, kinetic and mechanism modeling. J. Hazard. Mater. 2008, 159, 574-579. [CrossRef] [PubMed]

98. Bulut, E.; Ozacar, M. Adsorption of malachite green onto bentonite: Equilibrium and kinetic study and process design. Microporous Mesoporous Mater. 2008, 115, 234-246. [CrossRef]

99. Arabkhani, P.; Asfaram, A. Development of a novel three-dimensional magnetic polymer aerogel as an efficient adsorbent for malachite green removal. J. Hazard. Mater. 2020, 384, 121394. [CrossRef]

100. Gündüz, F.; Bayrak, B. Biosorption of malachite green from an aqueous solution using pomegranate peel: Equilibrium modelling, kinetic and thermodynamic studies. J. Mol. Liq. 2017, 243, 790-798. [CrossRef]

101. Vijayaraghavan, K.; Premkumar, Y.; Jegan, J. Malachite green and crystal violet biosorption onto coco-peat: Characterization and removal studies. Desalin. Water Treat. 2016, 57, 6423-6431. [CrossRef]

102. Panahi, M.; Behnam, S. Biosorption of Malachite Green dye by the brown alga Dictyota cervicornis: Kinetics and isotherm study. Color. Technol. 2018, 134, 292. [CrossRef]

103. Escudero, L.B.; Agostini, E.; Dotto, G.L. Application of tobacco hairy roots for the removal of malachite green from aqueous solutions: Experimental design, kinetic, equilibrium, and thermodynamic studies. Chem. Eng. Commun. 2018, 205, 122-133. [CrossRef]

104. Hamitouche, A.; Haffas, M.; Boudjemaa, A.; Benammar, S.; Sehailia, M.; Bachari, K. Efficient biosorption of methylene blue, malachite green and methyl violet organic pollutants on biomass derived from Anethum graveolens: An eco-benign approach for wastewater treatment. Desalin. Water Treat. 2017, 5, 225-236. [CrossRef] 